\title{
Systematic Review of COVID-19 Treatment and Management
}

\author{
Chijioke Gospel Tonycheta \\ Lithuanian Sports University, Kaunas, Lithuania
}

\begin{abstract}
COVID-19 is an emerging infectious disease, first reported in Wuhan, China. The deadly disease currently known as SARS-CoV-2 can affect everyone regardless of race, gender or age. However, people suffering from underlying medical conditions such as hypertension, diabetes, and other chronic diseases are at the biggest risk for developing more intense symptoms and complications. The global challenge in the containment of COVID-19 has led to a massive death rate and resulted in many economic, social, and health burdens around the world, leading to the question of the dynamic of COVID-19 management treatment. Therefore, this paper aimed to systematically review different past and present studies to develop a possible solution on how COVID-19 can be managed and treated. The articles were searched from five online databases: Science Direct, PubMed/Medline, Web of Science, Embase, and Scopus. The systematic review was guided by the guidelines presented in the preferred reporting items for systematic reviews and meta-analyses (PRISMA) from 2019-2021. Thirteen articles were included after reviewing seventy-two articles. Three hypotheses guided the study; clinical management, telehealth technology, and performance intelligence as an effective way of managing and controlling COVID-19. The study concludes there is no proven treatment for the virus yet, but clinical treatment, telehealth technology, and performance intelligence can effectively manage and control the virus. It also recommends policymakers should support the development and the implementation of performance intelligence based on the evidence and standardized data available for effective and pandemic resilience health care systems that will address the control and management of the virus.
\end{abstract}

Keywords: SARS2, SARS-CoV-2, Novel Coronavirus, 2019nCoV, COVID-19.

\section{INTRODUCTION}

$\mathrm{C}$ oronavirus disease 2019 (COVID-19), caused by SARS-CoV-2, is the causative agent of a potentially deadly illness that is a significant public health issue worldwide (Rothan et al., 2020). The severe acute respiratory syndrome coronavirus-2 (SARS-CoV-2) has affected millions worldwide due to its high incidence and lengthy incubation times, which are also without symptoms (Chung et al., 2021). On April 25th, 2021, WHO confirmed $151,803,822$ cases and 3,186,538 death reports worldwide.

People with chronic conditions such as hypertension, cardiovascular disease, diabetes mellitus, chronic obstructive pulmonary disease are at high risk of getting COVID-19. Neither a vaccine nor a specific antiviral drug is available to treat critically ill patients. The management of patients mainly focuses on providing supportive care, e.g., oxygenation, ventilation, and fluid management (Cunningham et al., 2020).

COVID-19 was discovered in patients having severe pneumonia and flu-like symptoms (Khursheed et al., 2020) in Wuhan, China. The airborne virus spreads by direct, indirect, or close contact with infected people through secretions such as saliva, respiratory secretions, or their respiratory droplets, making it highly contagious (Rajiv et al., 2020). The main COVID-19 symptoms

Copyright (C) 2021 Chijioke Gospel Tonycheta. Published by Lithuanian Sports University.

This is an Open Access article distributed under the terms of the Creative Commons Attribution 4.0 International License, which permits unrestricted use, distribution, and reproduction in any medium, provided the original author and source are credited. 
include fever, myalgia, and fatigue, with occasional headaches, hemoptysis, and septum production.

The presence of ongoing cases and mortality worldwide; the challenges in containing the virus (Dao et al., 2021); and the global burden in the social, economic, environmental, and health section has to lead to the usage of systematic review to identify, evaluate, and summarize the findings of all relevant research studies over the treatment and preventive measures taken to reduce the transmission of COVID-19. This systematic review looks into literature about how successful the SARS-CoV-2 management was - effective or ineffective - thereby informing the literature to base the conclusion.

Aim: To analyze the systematic review based on different past and present studies to develop a possible solution on how COVID-19 can be managed and treated.

Objectives: This systematic review seeks to:

1. Review available literature to bring to light management strategies of the pandemic.

2. Review literature to expose some of the challenges already met in dealing with COVID-19.

3. Improve the reporting of recent studies on the management and control of COVID-19. It will also contribute to advancing the innovation and methodology for practitioners and researcher's benefit.

4. Enumerate system indicators of achievements and failures to form the next course of action.

Hypothesis:

Clinical treatment, telehealth technology, and performance intelligence can effectively manage and control the virus.

\section{METHODS}

\section{Study design and nature of research}

The study design used is qualitative research that is implemented to gain more profound knowledge and insights into the treatment and management plans of COVID-19 and likewise the challenges faced by the researcher. This paper's study design was a systematic review of articles, journals, and studies on COVID-19 management (the role of Telehealth and clinical management, among others). The systematic review was guided by the guidelines presented in the preferred reporting items for systematic reviews and metaanalyses (PRISMA), as demonstrated in Fig.1 in the appendix section. In addition, the study selected a concrete method of a systematic review to allow a reproducible and robust approach. This approach made it easy for the researcher to structure current and existing evidence as far as a critical synthesis is concerned. However, this study did not register the protocol for the present systematic review considering that there was limited availability of evidence and the necessity of the matter at hand.

\section{Data sources}

The study reviewed articles searched from five online databases; Science Direct, PubMed/ Medline, Web of Science, Embase, and Scopus. The researcher searched articles on COVID-19 management and treatment. These articles were not just relevant but also relevant studies. An elementary search conducted on 29 January 2021 identified different studies with evidence that could be used to address the research problem, especially the role of telemedicine in managing and treating COVID-19, clinical treatment of COVID-19, and the management of COVID-19 within as well as outside of health care systems among others. Another search was conducted on the same day to determine if other studies were left out that can be relevant for the present study. The research used a combination of keywords and Medical Subject Headings (MeSH) such as SARS2, SARS-CoV-2, Wuhan Coronavirus, Novel Coronavirus, 2019nCoV, coronavirus, and COVID-19. The researcher consulted a librarian at this phase to confirm if the search conducted was satisfactory. Accordingly, the researcher adopted the search in each database. The researcher also conducted web-based resources manually of studies published on Google Scholar and Google on specific websites such as the Centers for Disease Control and Prevention, the World Health Organization, the National Administration of Traditional Chinese Medicine, the National Health Commission of the People's Republic of China, and the National Institute for Health and Clinical Excellence. To identify other studies that would have been left out during the preliminary searches, the researcher also conducted a systematic review of selected article references.

\section{Eligibility criteria}

Studies that reported findings on COVID-19 management and treatment were all included in the study for analysis. For instance, if the study defined and explained the management and treatment of COVID-19, its diagnosis, and prevention, it was added to the searched studies and included for 
analysis. These studies were also required to have been written in the English language, be published in the last two years, and peer-reviewed in the case of journals. The most relevant studies were those published in December of 2019. The selection of this date coincides with the fact the COVID-19 appeared in Wuhan, China, in December 2019. The researcher included all studies reporting findings on the management and treatment of COVID-19, tools and approaches used in this regard, supervision of the training of healthcare workers during the pandemic, consultation services of the disease, triage of patients, assessment of symptoms, diagnosis, and the provision of clinical services. However, studies and articles, letters, opinion articles, review articles with irrelevant data, duplicate publications, and articles with information that were inconsistent with the hypothesis were excluded.

Other inclusion criteria were:

1. All the studies that were published in English between December 2019 and January 2021.

2. All the studies that used primary and secondary data in peer-reviewed journals.

3. After selecting these studies, the researcher ensured that all these studies are in line with PICO standards (Liberati et al., 2009). PICO stands for 'Population Intervention, Comparison, and Outcome'.

a. P (population): all the members of the society at risk or infected with COVID-19.

b. I (intervention): is not necessary. Some studies measured the population's preparedness to COVID-19; others measured the effectiveness of COVID-19 measures and vaccines; others outlined approaches that can be used to control and manage COVID-19.

c. C (comparison): People infected with the COVID-19 virus compared with those who are not infected but are at risk of infection.

d. O (Output): the studies must elaborate on different measures that have been used or can be used to control and manage COVID-19.

\section{Search Strategy}

The researcher and his assistants searched five electronic databases; Science Direct, PubMed/ Medline, Web of Science, Embase, Scopus. The researcher and his team utilized a combination of filters and keywords. During the search, the researcher used the Boolean logic commands, after which the results were sorted based on relevance. The researcher, together with two research assistants, conducted the literature search. Also, they abided by the exclusion and inclusion criteria application independently. The studies' abstracts and titles were used to screen the studies for inclusion and exclusion before data extraction and analysis. The researchers then obtained the full-text studies and examined them after the initial screening of all the identified papers. This examination also ensured that all the studies for analysis meet the eligibility criteria. All the papers that fulfilled the eligibility criteria were used for data extraction and reviewed. Data were then extracted and analyzed according to the studies' contribution in addressing the research question. The researcher also searched references from relevant articles to complement the already searched articles. The research strategy is demonstrated in Table 1.

Following the literature search, identification of studies, and screening, 72 relevant studies in fulltext were identified and examined, as demonstrated in Table 2 in the appendix section. This finding was arrived at after duplicate studies were removed and studies screened using titles and abstracts. Fortysix articles of the remaining studies failed to meet the eligibility criteria of inclusion. Therefore, these studies were removed. However, the researcher added one study after screening the references. This activity was done through screening reference by reference. Finally, thirteen studies were included in the study, and their evidence was synthesized. This is demonstrated in Table 2 and 3 in the appendix section.

\section{Quality assessment of data}

The Critical Appraisal Skills Program (CASP) was used to assess the quality of the data drawn from the identified studies using various checklists. The researcher used the CASP tools developed for teaching people how to appraise different types of data critically (Monaghesh et al., 2020). To assess the quality of the collected data, the researcher categorized the studies into three classes; good, medium, and poor.

\section{Methods of statistical analysis}

The research conducted a narrative synthesis of all the data collected to synthesize and express all studies' results for analysis. There was a contrasting and comparison of the collected information. The researcher followed three key stages in the narrative synthesis. These stages included the preliminary synthesis development, the exploration of the 
relationship between the selected and analyzed studies, and the determination of the sturdiness and strength of the synthesis or analysis. Lastly, the researcher qualitatively described and presented the synthesized data.

\section{Characteristics of the studies included for synthesis:}

Most of the studies included in the stage of synthesis had common characteristics. For instance, some studies had been published in international journals from December 2019, and most were conducted in the United States of America. The thirteen studies included in this study for synthesis were conducted in different countries; seven in the United States of America, two in Iran, three in China, and one in Brazil. Some of the data collection tools used in these studies were e-mail, live video conferencing, and the telephone because the current COVID-19 pandemic discourages one-on-one contact between the interviewer and respondent.

Therefore, this paper's systematic review included thirteen studies that the researcher appraised using CASP tools. The researcher found that the quality of the studies assessed was generally high. For instance, $80 \%$ of the studies were rated as having good quality, and $20 \%$ were rated under medium quality. In addition, the researcher excluded any study that failed to meet quality standards.

\section{DISCUSSION}

This systematic review aimed to examine the management and treatment of COVID-19. When broken down further, it assessed the prevention, diagnosis, treatment, and control of coronavirus pandemic. Generally, a global pandemic results in anxiety and fear for many people in their households and communities. Studies have demonstrated that those having multiple comorbidities, preexisting conditions, and elderly people are the most vulnerable populations for worse outcomes of COVID-19. Therefore, COVID-19 presents a serious threat to these populations and all human populations in the world.

Additionally, health care providers and personnel are strained beyond the limit in most countries and face an unprecedented and overwhelming challenge as far as the delivery of care to COVID-19 patients is concerned. Therefore, the most vulnerable population must receive adequate emotional care. Similarly, those experiencing high-stress levels will determine where society moves during this pandemic as far as resilience is concerned. Published journals and reports on the experience of clinical treatment of the virus and other clinical trials not mentioned in this paper are primarily descriptive reports and case series from countries that are heavily hit by the virus. Interpreting outcomes from such studies must be conducted cautiously because of the dynamics of varied clinical outcomes, treatments, complications, clinical severity, treatment approaches, shifting testing, and changing demographics from one study to another.

The guidance provided by the Centers for Disease Control and Prevention for clinical care of COVID-19 patients in November 2020 emphasizes that there is no single treatment for the virus. It recommends that COVID-19 cases should be managed promptly. It also asserts that the health care personnel and the general public should implement all control and prevention measures as recommended by $\mathrm{WHO}$ and the government as an important way of managing the virus and its complications when it comes to treatment. From the systematic reviews, it is now clear that corticosteroids should not be used to treat COVID-19 patients unless there are compelling reasons for severe conditions. Similarly, investigative therapeutics such as remdesivir can be used as an option either as ongoing clinical trials or for compassionate use. Therefore, there is no current evidence that can be used to recommend a specific treatment as the safest and effective treatment of COVID-19.

Also, this review explains how Telehealth can be used to manage and treat the pandemic effectively. Today, the best preventive strategy that can be used to avoid the disease is by preventing exposure to the virus. This strategy is common and popular since there is no cure for the virus in the world (Kucharski et al., 2020). Fortunately, different organizations have developed vaccines, but social distancing and avoiding exposure remain the most effective ways to prevent the virus. Some other approaches and strategies have been proposed regarding infection, prevention, and management or coronavirus control. These techniques can reduce one's exposure to risks of contracting the virus, such as wearing face masks in public, covering nose and mouth when sneezing and coughing, constantly washing hands with running water and soap, and sanitizing with a liquid containing $60 \%$ alcohol. Other strategies 
include avoiding places, keeping a social distance of 1.5 meters, and not touching mouth, nose, or eyes with unwashed hands (Adhikari et al., 2020). Monaghesh \& Hajizadeh (2020) argue that reducing physical contact between the patients and health care providers will require that telecommunication tools are used to triage, assess, and care for patients of COVID-19. For instance, a simple mobile call or live video conferencing may allow health care workers to ask special questions and gather data, supply consultation, triage, assess, and monitor patients. Telehealth services can also be used for regular check-ins such as blood pressure, respiratory needs, and oxygen required at a residence.

When COVID-19 broke out in Wuhan, China, different scholars conducted online surveys on mental health using various communication programs such as TikTok, We Chat, and Weibo. These surveys allowed the researchers and mental health professionals to provide safe mental care services, especially during the COVID-19 pandemic period (Liu et al., 2020). As a result, China's government came up with a remote consultation network that supports telephone and internet consultations in a safe background or context. This approach ensured that coronavirus patients are provided with mental health services and ultimately reduce or diminish the cross infection risks (Jiang et al., 2020). Similarly, the Chinese National Health Commission published several guidelines online and provided free electronic books educating the public about COVID-19. According to Li et al. (2020), this approach aimed to aid the emergency intervention among the Chinese people. It was also to help promote their safety and improve the effectiveness and quality of emergency interventions. Another study conducted by Zhou et al. (2020) on the role of Telehealth in mental health as a result of coronavirus observes that it reduces the burden of mental health to a patient from the virus as he can share information freely about anxiety, depression, and symptoms of burnout from an isolation facility.

Greenhalgh et al. (2020) suggested that the use of Telehealth in the management and treatment of COVID-19 presents a lot of benefits as far as the provision of allergy as well as immunology services by reducing the exposure that health care workers can have to patients infected with the virus. The patients also can have access to rapid evaluation for the infection of COVID-19 (Shaker et al., 2020). This study argues in favor of telehealth services and against traditional approaches used in diagnosing COVID-19. Their argument is supported by identifying a new strategy for screening and triaging patients of COVID-19 in Iran. In response to the shortage of conventional approaches for diagnosing the virus, the Iranian Society of Radiology (ISR) delivered social media massages to triage the virus infection through teleconsultation and teleradiology services (Davarpanah et al., 2020). Another study by Yang et al. (2020) added that the health and safety of patients and medical staff can be guaranteed if mobile health technology is developed by health care management. This technology can also be used for billing and staffing plans.

The results of this paper demonstrate that managing and treating COVID-19 presents many easy to adopt and implement potentials, especially in phone calls and live video conferencing, among others. Live video conferencing allows the patients and health care providers to avoid direct physical contact, which reduces the risks of exposure to the virus and prevents transmission of the virus from one person to another (Reeves et al., 2020). Live video also has other benefits, especially to coronavirus patients who seek consultations. It is also beneficial for people with anxiety disorders who dislike in-person visits to review their chronic illnesses such as cancer and diabetes. It is also essential when triage by telephone is insufficient and for some people who want to carry out some medication checks. Controlling and managing COVID-19 will require phone follow-ups and video consultations in multiple cancer settings such as prostate, colorectal, endometrial, and lung. This approach will reduce exposure to risks that can lead to infections of COVID-19.

A study conducted in the United States of America posits that electronic health records (EHR) and phone calls facilitate treating and screening patients without them showing up in person. It also improves decision-making among healthcare providers' teams, especially in urgent and ambulatory care (Reeves et al., 2020). Ideally, Telehealth's prominent role in the management and treatment of COVID-19 is the prevention of morbidity. It also helps in reducing congestion in waiting rooms to reduce risks of exposure to potentially infected people. Also, populations vulnerable to coronavirus, such as elderly people and those living with underlying conditions, can use their electronic devices to access health services. Finally, the health care providers and members 
of the public need to be trained on how they can exploit and use telehealth tools, especially at this time, to help manage and treat COVID-19.

Monitoring and managing COVID-19 requires different research perspectives such as economics, management, political and behavioral sciences, sociology, epidemiology, public health, and health services research. The key emphasis of performance intelligence is that there must be different research perspectives to support the decision-making process in health systems to determine evidencebased and well-informed policies and improve the whole system to cope and manage as well as control the virus. Therefore, managing and controlling COVID-19 becomes an integral of governing health care systems and not merely as an identical aspect with its rationale.

The current concern in the COVID-19 era is the treatment of new cases. However, the challenges posed to the health systems by the pandemic go beyond this current concern. For instance, there is an emerging risk of crowded non-COVID-19 patients at health care facilities. This reality makes management and control of the virus complicated. In addition, the majority of people needing care from healthcare systems are non-COVID-19 patients, thus presenting a considerable risk.

Health systems delay many elective procedures for non-COVID-19 patients to maximize the capacity of caring for the patients suffering from the virus. Studies conducted by Campbell (2020) and Nelson (2020) observe that some patients are refraining from seeking care because of fear of contracting the virus from a contaminated hospital. The studies also reveal that patients refrain because they feel that they should not burden health care providers with their 'minor' issues. Another study by Kringos et al. (2020) posited that the effect of patients needing semi-acute care is becoming a public health crisis, since most hospitals have reported reduced utilization of essential services. Additionally, there are some significant changes in how health care workers deliver care to nonCOVID-19 patients as some protocols have been modified (Rosenbaum, 2020).

Performance reporting, monitoring, and evaluation can support the balancing system approach in the management and control of not just COVID-19 but also any other pandemics. These approaches allow for targeted strategies such as predicting accurate admissions in hospitals and long-term, home, and primary care needs of
COVID-19 patients after discharge. Performance intelligence can also make rational and needsbased solutions a compelling solution in monitoring and managing the virus. Studies have revealed that health care performance intelligence plays a significant role in guiding and informing actors' decisions in health care systems (Carinci et al., 2015). International, regional, and national experiences should be translated into approaches and solutions of managing and controlling COVID-19 and its impact on societies and health systems. There is a need for comparative health system research and its data to influence or inform response models inhospital care and primary care and in public health, social care, and long-term care. Responses must address the care continuum of COVID-19 patients in prevention, diagnosis, treatment, and follow-up. Epidemiological approaches must be employed at every stage, considering the cultural, political, organizational, and regulatory context.

Health care stakeholders can use performance intelligence to collect data that can be compared from one region to another, and establish mechanisms and identify practical approaches for managing controlling the virus. For instance, the COVID-19 response team could use performance intelligence to select at least one of the following: avoid disruption in the manner in which continuum of care is delivered; analyze different potential populations' behavioral models as well as that of the health care professionals; significantly improve and optimize the infrastructure of information by linking data to various databases; undertake disruptive intervention using new approaches and technologies such as telehealth technologies; swap tasks between professions and specialties based on the capacity needed at the hospital facilities, and substituting the effects of COVID-19 from hospital care to primary care for different patients owing to the severity of the symptoms and circumstances.

\section{CONCLUSIONS}

This study offers a comprehensive systematic review of the management and treatment of COVID-19. After a thorough review of relevant information on the disease, this paper makes the following conclusions:

1. As this virus continues to ravage some parts of the world, there is a need to break away from conventional strategies and understand different new ways that can be used to manage and treat it, such as Telehealth. COVID-19 has presented 
a lot of challenges in all sectors, including the health sector. It has infected and affected many people, leaving needs unmet as far as providing health care services.

2. There must be innovative ways to prevent transmissions, improve diagnosis in a safe environment, and treat those affected while keeping the general population safe. Performance intelligence is an essential factor when it comes to the management and treatment of COVID-19. It guides the strategy taken by public health officials and other actors of the health system as far as implementation and contextualization of approaches to address the virus is concerned.

3. There is a need for related systems of indicators and standardized data commonly agreed across the world to effectively use health information structures in the management and control of COVID-19. However, clinical treatment reviews as an effective way of managing and controlling COVID-19 on non-pharmacological and pharmacological therapies are significantly increasing day by day. Nonetheless, many of them still lack methodological clarity, thus hindering definite generalizable conclusions regarding the safety and efficacy of the therapeutic intervention on treatment and management of COVID-19. For instance, there is little information on the available treatments' cost-effectiveness, especially in developing countries. Therefore, there is a need for properly designed evidence-based clinical trials with an adequate sample size across different parts of the world to generate reliable results regarding the use of clinical treatment of the virus in the short run and the long run.

4. There is not adequate data to particularly recommend specific treatment to be used anywhere from the study's analysis.

\section{REFERENCES}

Adhikari, S. P., Meng, S., Wu, Y. J., Mao, Y. P., Ye, R. X., Wang, Q. Z., Sun, C., Sylvia, S., Rozelle, S., Raat, H., \& Zhou, H. (2020). Epidemiology, causes, clinical manifestation and diagnosis, prevention and control of coronavirus disease (COVID-19) during the early outbreak period: a scoping review. Infectious diseases of poverty, 9(1), 29. https://doi.org/10.1186/s40249-02000646-X

Annis, T., Pleasants, S., Hultman, G., Lindemann, E., Thompson, J.A., Billecke, S., Badlani, S., \& Melton, G. B. (2020). Rapid implementation of a COVID-19 remote patient monitoring program. Journal of the American Medical Informatics Association : JAMIA, 27(8), 13261330. https://doi.org/10.1093/jamia/ocaa097

Antwi-Amoabeng, D., Kanji, Z., Ford, B., Beutler, B. D., Riddle, M. S., \& Siddiqui, F. (2020). Clinical outcomes in COVID-19 patients treated with tocilizumab: An individual patient data systematic review. Journal of medical virology, 92(11), 2516-2522. https://doi. org/10.1002/jmv.26038

Binkin, N., Michieletto, F., Salmaso, S., \& Russo, F. (2020). Protecting our health careworkers while protecting our communities during the COVID-19 pandemic: A comparison of approaches and early outcomes in two Italian regions, 2020. MedRxiv, 2020.04.10.20060707. https://doi.org/10.1101/2020.04.10.20060707

Bokolo Anthony Jnr (2020). Use of Telemedicine and Virtual Care for Remote Treatment in Response to COVID-19 Pandemic. Journal of medical systems, 44(7), 132. https://doi.org/10.1007/s10916-020-01596-5

Borges do Nascimento, I. J., Cacic, N., Abdulazeem, H. M., von Groote, T. C., Jayarajah, U., Weerasekara, I., Esfahani, M. A., Civile, V. T., Marusic, A., Jeroncic, A.,
Carvas Junior, N., Pericic, T. P., Zakarija-Grkovic, I., Meirelles Guimarães, S. M., Luigi Bragazzi, N., Bjorklund, M., Sofi-Mahmudi, A., Altujjar, M., Tian, M., Arcani, D., ... Marcolino, M. S. (2020). Novel Coronavirus Infection (COVID-19) in Humans: A Scoping Review and Meta-Analysis. Journal of clinical medicine, 9(4), 941. https://doi.org/10.3390/jcm9040941

Carinci F. (2020). Covid-19: preparedness, decentralisation, and the hunt for patient zero. BMJ (Clinical research ed.), 368, bmj.m799. https://doi. org/10.1136/bmj.m799

Carinci F. (2020). Covid-19: preparedness, decentralisation, and the hunt for patient zero. $B M J$ (Clinical research ed.), 368, bmj.m799. https://doi. org/10.1136/bmj.m799

Carinci, F., Van Gool, K., Mainz, J., Veillard, J., Pichora, E. C., Januel, J. M., Arispe, I., Kim, S. M., Klazinga, N. S., \& OECD Health Care Quality Indicators Expert Group (2015). Towards actionable international comparisons of health system performance: expert revision of the OECD framework and quality indicators. International journal for quality in health care : journal of the International Society for Quality in Health Care, 27(2), 137-146. https://doi.org/10.1093/ intqhe/mzv004

Carinci, F., Van Gool, K., Mainz, J., Veillard, J., Pichora, E. C., Januel, J. M., Arispe, I., Kim, S. M., Klazinga, N. S., \& OECD Health Care Quality Indicators Expert Group (2015). Towards actionable international comparisons of health system performance: expert revision of the OECD framework and quality indicators. International journal for quality in health care : journal of the International Society for Quality 
in Health Care, 27(2), 137-146. https://doi.org/10.1093/ intqhe/mzv004

Carr P. R. (2020). If Everything Has Changed, Why Such a Focus on Bailing Out Capitalism? The Somber Reality Underpinning Covid-19. Postdigital Science and Education, 1-7. Advance online publication. https://doi. org/10.1007/s42438-020-00115-6

Chan, D. S., Callahan, C. W., Sheets, S. J., Moreno, C. N., \& Malone, F. J. (2003). An Internet-based store-andforward video home telehealth system for improving asthma outcomes in children. American journal of health-system pharmacy : AJHP : official journal of the American Society of Health-System Pharmacists, 60(19), 1976-1981. https://doi.org/10.1093/ajhp/60.19.1976

Charles B. L. (2000). Telemedicine can lower costs and improve access. Healthcare financial management : journal of the Healthcare Financial Management Association, 54(4), 66-69.

Chung, J. Y., Thone, M. N., \& Kwon, Y. J. (2021). COVID-19 vaccines: The status and perspectives in delivery points of view. Advanced drug delivery reviews, 170, 1-25. https://doi.org/10.1016/j. addr.2020.12.011

Cunningham, A. C., Goh, H. P., \& Koh, D. (2020). Treatment of COVID-19: old tricks for new challenges. Critical care (London, England), 24(1), 91. https://doi.org/10.1186/s13054-020-2818-6

Dao, T. L., Hoang, V. T., \& Gautret, P. (2021). Recurrence of SARS-CoV-2 viral RNA in recovered COVID-19 patients: a narrative review. European journal of clinical microbiology \& infectious diseases : official publication of the European Society of Clinical Microbiology, 40(1), 13-25. https://doi.org/10.1007/s10096-020-04088-z

Davarpanah, A. H., Mahdavi, A., Sabri, A., Langroudi, T. F., Kahkouee, S., Haseli, S., Kazemi, M. A., Mehrian, P., Mahdavi, A., Falahati, F., Tuchayi, A. M., Bakhshayeshkaram, M., \& Taheri, M. S. (2020). Novel Screening and Triage Strategy in Iran During Deadly Coronavirus Disease 2019 (COVID-19) Epidemic: Value of Humanitarian Teleconsultation Service. Journal of the American College of Radiology : JACR, 17(6), 734-738. https://doi.org/10.1016/j.jacr.2020.03.015

Davies, N. G., Jarvis, C. I., CMMID COVID-19 Working Group, Edmunds, W. J., Jewell, N. P., Diaz-Ordaz, K., \& Keogh, R. H. (2021). Increased hazard of death in community-tested cases of SARS-CoV-2 Variant of Concern 202012/01. medRxiv : the preprint server for health sciences, 2021.02.01.21250959. https://doi. org/10.1101/2021.02.01.21250959

Dhand, R., \& Li, J. (2020). Coughs and Sneezes: Their Role in Transmission of Respiratory Viral Infections, Including SARS-CoV-2. American journal of respiratory and critical care medicine, 202(5), 651-659. https://doi. org/10.1164/rccm.202004-1263PP

Doarn, C. R., Latifi, R., Poropatich, R. K., Sokolovich, N., Kosiak, D., Hostiuc, F., Zoicas, C., Buciu, A., \& Arafat, R. (2018). Development and Validation of Telemedicine for Disaster Response: The North Atlantic Treaty Organization Multinational System. Telemedicine journal and e-health: the official journal of the American
Telemedicine Association, 24(9), 657-668. https://doi. org/10.1089/tmj.2017.0237

Emanuel, E. J., Persad, G., Upshur, R., Thome, B., Parker, M., Glickman, A., Zhang, C., Boyle, C., Smith, M., \& Phillips, J. P. (2020). Fair Allocation of Scarce Medical Resources in the Time of Covid-19. The New England journal of medicine, 382(21), 2049-2055. https://doi.org/10.1056/NEJMsb2005114

Fajgenbaum, D. C., Khor, J. S., Gorzewski, A., Tamakloe, M. A., Powers, V., Kakkis, J. J., Repasky, M., Taylor, A., Beschloss, A., Hernandez-Miyares, L., Go, B., Nimgaonkar, V., McCarthy, M. S., Kim, C. J., Pai, R. L., Frankl, S., Angelides, P., Jiang, J., Rasheed, R., Napier, E., ... Pierson, S. K. (2020). Treatments Administered to the First 9152 Reported Cases of COVID-19: A Systematic Review. Infectious diseases and therapy, 9(3), 435-449. https://doi.org/10.1007/s40121-020-00303-8

Fisher, D., \& Heymann, D. (2020). Q\&A: The novel coronavirus outbreak causing COVID-19. BMC medicine, 18(1), 57. https://doi.org/10.1186/s12916020-01533-w

Fortney, J. C., Pyne, J. M., Edlund, M. J., Williams, D. K., Robinson, D. E., Mittal, D., \& Henderson, K. L. (2007). A randomized trial of telemedicine-based collaborative care for depression. Journal of general internal medicine, 22(8), 1086-1093. https://doi.org/10.1007/ s11606-007-0201-9

Fu, L., Wang, B., Yuan, T., Chen, X., Ao, Y., Fitzpatrick, T., Li, P., Zhou, Y., Lin, Y. F., Duan, Q., Luo, G., Fan, S., Lu, Y., Feng, A., Zhan, Y., Liang, B., Cai, W., Zhang, L., Du, X., Li, L., ... Zou, H. (2020). Clinical characteristics of coronavirus disease 2019 (COVID-19) in China: A systematic review and meta-analysis. The Journal of infection, 80(6), 656-665. https://doi.org/10.1016/j. jinf.2020.03.041

Gautret, P., Lagier, J. C., Parola, P., Hoang, V. T., Meddeb, L., Mailhe, M., Doudier, B., Courjon, J., Giordanengo, V., Vieira, V. E., Tissot Dupont, H., Honoré, S., Colson, P., Chabrière, E., La Scola, B., Rolain, J. M., Brouqui, P., \& Raoult, D. (2020). Hydroxychloroquine and azithromycin as a treatment of COVID-19: results of an open-label non-randomized clinical trial. International journal of antimicrobial agents, 56(1), 105949. https://doi.org/10.1016/j. ijantimicag.2020.105949

Gbinigie, K., \& Frie, K. (2020). Should chloroquine and hydroxychloroquine be used to treat COVID-19? A rapid review. BJGP open, 4(2), bjgpopen20X101069. https:// doi.org/10.3399/bjgpopen20X101069

Goumenou, M., Sarigiannis, D., Tsatsakis, A., Anesti, O., Docea, A. O., Petrakis, D., Tsoukalas, D., Kostoff, R., Rakitskii, V., Spandidos, D. A., Aschner, M., \& Calina, D. (2020). COVID19 in Northern Italy: An integrative overview of factors possibly influencing the sharp increase of the outbreak (Review). Molecular medicine reports, 22(1), 20-32. https://doi.org/10.3892/ $\underline{\mathrm{mmr} .2020 .11079}$

Greenhalgh, T., Koh, G., \& Car, J. (2020). Covid-19: a remote assessment in primary care. BMJ (Clinical research ed.), 368, m1182. https://doi.org/10.1136/bmj. $\underline{\mathrm{m} 1182}$ 
Grisolia, G., Franchini, M., Glingani, C., Inglese, F., Garuti, M., Beccaria, M., Capuzzo, M., Pinto, A., Pavan, G., Righetto, L., Perotti, C., Zampriolo, P., \& De Donno, G. (2020). Convalescent plasma for coronavirus disease 2019 in pregnancy: a case report and review. American journal of obstetrics \& gynecology $M F M, \quad 2(3), \quad 100174 . \quad$ https://doi.org/10.1016/j. ajogmf.2020.100174

Grubaugh, N. D., Petrone, M. E., \& Holmes, E. C. (2020). We shouldn't worry when a virus mutates during disease outbreaks. Nature microbiology, 5(4), 529-530. https://doi.org/10.1038/s41564-020-0690-4

Haines, A., de Barros, E. F., Berlin, A., Heymann, D. L., \& Harris, M. J. (2020). National UK programme of community health workers for COVID-19 response. Lancet (London, England), 395(10231), 11731175. https://doi.org/10.1016/S0140-6736(20)30735-2

Hou, Y. J., Chiba, S., Halfmann, P., Ehre, C., Kuroda, M., Dinnon, K. H., 3rd, Leist, S. R., Schäfer, A., Nakajima, N., Takahashi, K., Lee, R. E., Mascenik, T. M., Graham, R., Edwards, C. E., Tse, L. V., Okuda, K., Markmann, A. J., Bartelt, L., de Silva, A., Margolis, D. M., ... Baric, R. S. (2020). SARS-CoV-2 D614G variant exhibits efficient replication ex vivo and transmission in vivo. Science (New York, N.Y.), 370(6523), 1464-1468. https://doi. org/10.1126/science.abe8499

Howard, I. M., \& Kaufman, M. S. (2018). Telehealth applications for outpatients with neuromuscular or musculoskeletal disorders. Muscle \& nerve, 58(4), 475485. https://doi.org/10.1002/mus.26115

Ioannidis, J. P. (2020). A fiasco in the making? As the coronavirus pandemic takes hold, we are making decisions without reliable data. Stat, 17.

Jewell, N. P., Lewnard, J. A., \& Jewell, B. L. (2020). Caution Warranted: Using the Institute for Health Metrics and Evaluation Model for Predicting the Course of the COVID-19 Pandemic. Annals of internal medicine, 173(3), 226-227. https://doi.org/10.7326/ M20-1565

Jia, Y. B., Jiang, D. M., Ren, Y. Z., Liang, Z. H., Zhao, Z. Q., \& Wang, Y. X. (2017). Inhibitory effects of vitamin $\mathrm{E}$ on osteocyte apoptosis and DNA oxidative damage in bone marrow hemopoietic cells at early stage of steroid-induced femoral head necrosis. Molecular medicine reports, 15(4), 1585-1592. https://doi. org/10.3892/mmr.2017.6160

Jiang, X., Deng, L., Zhu, Y., Ji, H., Tao, L., Liu, L., Yang, D., \& Ji, W. (2020). Psychological crisis intervention during the outbreak period of new coronavirus pneumonia from experience in Shanghai. Psychiatry research, 286, 112903. Advance online publication. https://doi. org/10.1016/j.psychres.2020.112903

Khalili, M., Chegeni, M., Javadi, S., Farokhnia, M., Sharifi, H., \& Karamouzian, M. (2020). Therapeutic interventions for COVID-19: a living overview of reviews. Therapeutic advances in respiratory disease, 14, 1753466620976021. $\quad$ https://doi. org/10.1177/1753466620976021

Kimble, C., Coustasse, A., \& Maxik, K. (2021). Considerations on the distribution and administration of the new COVID-19 vaccines. International Journal of Healthcare Management, 14, 1-5. https://doi.org/10.108 $\underline{0 / 20479700.2020 .1859778}$

Koff, W. C., Schenkelberg, T., Williams, T., Baric, R. S., McDermott, A., Cameron, C. M., Cameron, M. J., Friemann, M. B., Neumann, G., Kawaoka, Y., Kelvin, A. A., Ross, T. M., Schultz-Cherry, S., Mastro, T. D., Priddy, F. H., Moore, K.A., Ostrowsky, J. T., Osterholm, M. T., \& Goudsmit, J. (2021). Development and deployment of COVID-19 vaccines for those most vulnerable. Science translational medicine, 13(579), eabd1525. https://doi.org/10.1126/scitranslmed.abd1525 Korber, B., Fischer, W. M., Gnanakaran, S., Yoon, H., Theiler, J., Abfalterer, W., Hengartner, N., Giorgi, E. E., Bhattacharya, T., Foley, B., Hastie, K. M., Parker, M. D., Partridge, D. G., Evans, C. M., Freeman, T. M., de Silva, T. I., Sheffield COVID-19 Genomics Group, McDanal, C., Perez, L. G., Tang, H., ... Montefiori, D. C. (2020). Tracking Changes in SARS-CoV-2 Spike: Evidence that D614G Increases Infectivity of the COVID-19 Virus. Cell, 182(4), 812-827.e19. https://doi. org/10.1016/j.cell.2020.06.043

Kringos, D., Carinci, F., Barbazza, E., Bos, V., Gilmore, K., Groene, O., Gulácsi, L., Ivankovic, D., Jansen, T., Johnsen, S. P., de Lusignan, S., Mainz, J., Nuti, S., Klazinga, N., \& HealthPros Network (2020). Managing COVID-19 within and across health systems: why we need performance intelligence to coordinate a global response. Health research policy and systems, 18(1), 80. https://doi.org/10.1186/s12961-02000593-X

Kucharski, A. J., Russell, T. W., Diamond, C., Liu, Y., Edmunds, J., Funk, S., Eggo, R. M., \& Centre for Mathematical Modelling of Infectious Diseases COVID-19 working group (2020). Early dynamics of transmission and control of COVID-19: a mathematical modelling study. The Lancet. Infectious diseases, 20(5), 553-558. https://doi.org/10.1016/ S1473-3099(20)30144-4

Law, S., Leung, A. W., \& Xu, C. (2021). COVID-19 mutation in the United Kingdom. Microbes and Infectious Diseases, 2(2), 187-188. https://doi.org/10.21608/ mid.2021.57042.1109

Leite, H., Gruber, T., \& Hodgkinson, I. (2019). Flattening the infection curve - understanding the role of telehealth in managing COVID-19. Leadership in Health Services, 33, 221-226. https://doi.org/10.1108/LHS-05-2020-084

Li, W., Yang, Y., Liu, Z. H., Zhao, Y. J., Zhang, Q., Zhang, L., Cheung, T., \& Xiang, Y. T. (2020). Progression of Mental Health Services during the COVID-19 Outbreak in China. International journal of biological sciences, 16(10), 1732-1738. https://doi.org/10.7150/ ijbs. 45120

Liu, S., Yang, L., Zhang, C., Xiang, Y. T., Liu, Z., Hu, S., \& Zhang, B. (2020). Online mental health services in China during the COVID-19 outbreak. The lancet. Psychiatry, 7(4), e17-e18. https://doi.org/10.1016/ $\underline{\mathrm{S} 2215-0366(20) 30077-8}$

Lukas, H., Xu, C., Yu, Y., \& Gao, W. (2020). Emerging Telemedicine Tools for Remote COVID-19 Diagnosis, 
Monitoring, and Management. ACS nano, 14(12), 16180-16193. https://doi.org/10.1021/acsnano.0c08494

Mainz, J., Hess, M. H., \& Johnsen, S. P. (2019). The Danish unique personal identifier and the Danish Civil Registration System as a tool for research and quality improvement. International journal for quality in health care : journal of the International Society for Quality in Health Care, 31(9), 717-720. https://doi.org/10.1093/ intqhe/mzz008

Marton, K., \& Kanas, N. (2016). Telehealth Modalities for Group Therapy: Comparisons to In-Person Group Therapy. International Journal of Group Psychotherapy, 66, 145-150. https://doi.org/10.1080/00207284.2015.10 $\underline{96109}$

Md Insiat Islam Rabby (2020). Current Drugs with Potential for Treatment of COVID-19: A Literature Review. Journal of pharmacy \& pharmaceutical sciences : a publication of the Canadian Society for Pharmaceutical Sciences, Societe canadienne des sciences pharmaceutiques, 23(1), 58-64. https://doi.org/10.18433/jpps31002

Mehra, M. R., Desai, S. S., Ruschitzka, F., \& Patel, A. N. (2020). RETRACTED: Hydroxychloroquine or chloroquine with or without a macrolide for treatment of COVID-19: a multinational registry analysis. Lancet (London, England), S0140-6736(20)31180-6. Advance online publication. https://doi.org/10.1016/S01406736(20)31180-6

Mehrotra, A., Jena, A. B., Busch, A. B., Souza, J., Uscher-Pines, L., \& Landon, B. E. (2016). Utilization of Telemedicine Among Rural Medicare Beneficiaries. JAMA, 315(18), 2015-2016. https://doi. org/10.1001/jama.2016.2186

Monaghesh, E., \& Hajizadeh, A. (2020). The role of telehealth during COVID-19 outbreak: a systematic review based on current evidence. BMC public health, 20(1), 1193. https://doi.org/10.1186/s12889-02009301-4

Murphy, J., Vallières, F., Bentall, R. P., Shevlin, M., McBride, O., Hartman, T. K., McKay, R., Bennett, K., Mason, L., Gibson-Miller, J., Levita, L., Martinez, A. P., Stocks, T., Karatzias, T., \& Hyland, P. (2021). Psychological characteristics associated with COVID-19 vaccine hesitancy and resistance in Ireland and the United Kingdom. Nature communications, 12(1), 29. https://doi.org/10.1038/s41467-020-20226-9

Nelson B. (2020). Covid-19 is shattering US cancer care. BMJ (Clinical research ed.), 369, m1544. https:// doi.org/10.1136/bmj.m1544

Odone, A., Delmonte, D., Scognamiglio, T., \& Signorelli, C. (2020). COVID-19 deaths in Lombardy, Italy: data in context. The Lancet. Public health, 5(6), e310. https://doi.org/10.1016/S2468-2667(20)30099-2

Ohannessian, R., Duong, T. A., \& Odone, A. (2020). Global Telemedicine Implementation and Integration Within Health Systems to Fight the COVID-19 Pandemic: A Call to Action. JMIR public health and surveillance, 6(2), e18810.https://doi.org/10.2196/18810 Pacheco, R. L., \& Riera, R. (2020). Hydroxychloroquine and chloroquine for COVID-19 infection. Rapid systematic review. Journal of Evidence-Based Healthcare, 2(1), 74-92. https://doi.org/10.17267/2675021Xevidence.v2i1.2843
Plante, J. A., Liu, Y., Liu, J., Xia, H., Johnson, B. A., Lokugamage, K. G., Zhang, X., Muruato, A. E., Zou, J., Fontes-Garfias, C. R., Mirchandani, D., Scharton, D., Bilello, J. P., Ku, Z., An, Z., Kalveram, B., Freiberg, A. N., Menachery, V. D., Xie, X., Plante, K. S., ... Shi, P. Y. (2021). Spike mutation D614G alters SARSCoV-2 fitness. Nature, 592(7852), 116-121. https://doi. org/10.1038/s41586-021-03657-2.

Preliminary genomic characterisation of an emergent SARS-CoV-2 lineage in the UK defined by a novel set of spike mutations-SARS-CoV-2 coronavirus / $n \mathrm{CoV}$ 2019 Genomic Epidemiology. (2020, December 18). Virological. https://virological.org/t/preliminary-genomiccharacterisation-of-an-emergent-sars-cov-2-lineage-in-theuk-defined-by-a-novel-set-of-spike-mutations/563

Rana, D. R., \& Dulal, S. (2020). Therapeutic Application of Chloroquine in Clinical Trials for COVID-19. MedRxiv, 2020.03.22.20040964. https://doi. org/10.1101/2020.03.22.20040964

Rana, D. R., \& Dulal, S. (2020). Therapeutic Application of Chloroquine in Clinical Trials for COVID-19. MedRxiv, 2020.03.22.20040964. https://doi. org/10.1101/2020.03.22.20040964

Reeves, J. J., Hollandsworth, H. M., Torriani, F. J., Taplitz, R., Abeles, S., Tai-Seale, M., Millen, M., Clay, B. J., \& Longhurst, C. A. (2020). Rapid response to COVID-19: health informatics support for outbreak management in an academic health system. Journal of the American Medical Informatics Association : JAMIA, 27(6), 853-859. https://doi.org/10.1093/jamia/ ocaa037

Rosenbaum L. (2020). The Untold Toll - The Pandemic's Effects on Patients without Covid-19. The New England journal of medicine, 382(24), 2368-2371. https://doi. org/10.1056/NEJMms2009984

Rothan, H. A., \& Byrareddy, S. N. (2020). The epidemiology and pathogenesis of coronavirus disease (COVID-19) outbreak. Journal of autoimmunity, 109, 102433. https://doi.org/10.1016/j.jaut.2020.102433

Sanyaolu, A., Okorie, C., Marinkovic, A., Patidar, R., Younis, K., Desai, P., Hosein, Z., Padda, I., Mangat, J., \& Altaf, M. (2020). Comorbidity and its Impact on Patients with COVID-19. SN comprehensive clinical medicine, 1-8. Advance online publication. https://doi. org/10.1007/s42399-020-00363-4

Sauers-Ford, H. S., Hamline, M. Y., Gosdin, M. M., Kair, L. R., Weinberg, G. M., Marcin, J. P., \& Rosenthal, J. L. (2019). Acceptability, Usability, and Effectiveness: A Qualitative Study Evaluating a Pediatric Telemedicine Program. Academic emergency medicine : official journal of the Society for Academic Emergency Medicine, 26(9), 1022-1033. https://doi.org/10.1111/ acem. 13763

Sellner, J., Jenkins, T. M., von Oertzen, T. J., Bassetti, C. L., Beghi, E., Bereczki, D., Bodini, B., Cavallieri, F., Di Liberto, G., Helbok, R., Macerollo, A., Maia, L. F., Oreja-Guevara, C., Özturk, S., Rakusa, M., Pisani, A., Priori, A., Sauerbier, A., Soffietti, R., Taba, P., ... EAN NeuroCOVID-19 Task Force (2021). A plea for equitable global access to COVID-19 diagnostics, vaccination and therapy: The NeuroCOVID-19 Task Force of the European Academy of Neurology. European 
journal of neurology, 10.1111/ene.14741. Advance online publication. https://doi.org/10.1111/ene.14741

Shaker, M. S., Oppenheimer, J., Grayson, M., Stukus, D., Hartog, N., Hsieh, E., Rider, N., Dutmer, C. M., Vander Leek, T. K., Kim, H., Chan, E. S., Mack, D., Ellis, A. K., Lang, D., Lieberman, J., Fleischer, D., Golden, D., Wallace, D., Portnoy, J., Mosnaim, G., ... Greenhawt, M. (2020). COVID-19: Pandemic Contingency Planning for the Allergy and Immunology Clinic. The journal of allergy and clinical immunology. In practice, 8(5), 14771488.e5. https://doi.org/10.1016/j.jaip.2020.03.012

Shaker, M. S., Oppenheimer, J., Grayson, M., Stukus, D., Hartog, N., Hsieh, E., Rider, N., Dutmer, C. M., Vander Leek, T. K., Kim, H., Chan, E. S., Mack, D., Ellis, A. K., Lang, D., Lieberman, J., Fleischer, D., Golden, D., Wallace, D., Portnoy, J., Mosnaim, G., ... Greenhawt, M. (2020). COVID-19: Pandemic Contingency Planning for the Allergy and Immunology Clinic. The journal of allergy and clinical immunology. In practice, 8(5), 14771488.e5. https://doi.org/10.1016/j.jaip.2020.03.012

Singh, A. K., Singh, A., Shaikh, A., Singh, R., \& Misra, A. (2020). Chloroquine and hydroxychloroquine in the treatment of COVID-19 with or without diabetes: A systematic search and a narrative review with a special reference to India and other developing countries. Diabetes \& metabolic syndrome, 14(3), 241246. https://doi.org/10.1016/j.dsx.2020.03.011

Smith, A. C., Thomas, E., Snoswell, C. L., Haydon, H., Mehrotra, A., Clemensen, J., \& Caffery, L. J. (2020). Telehealth for global emergencies: Implications for coronavirus disease 2019 (COVID-19). Journal of telemedicine and telecare, 26(5), 309-313. https://doi. org/10.1177/1357633X20916567

Tang, C., Wang, Y., Lv, H., Guan, Z., \& Gu, J. (2020). Caution against corticosteroid-based COVID-19 treatment. Lancet (London, England), 395(10239), 17591760. https://doi.org/10.1016/S0140-6736(20)30749-2

Tang, W., Cao, Z., Han, M., Wang, Z., Chen, J., Sun, W., Wu, Y., Xiao, W., Liu, S., Chen, E., Chen, W., Wang, X., Yang, J., Lin, J., Zhao, Q., Yan, Y., Xie, Z., Li, D., Yang, Y., Liu, L., ... Xie, Q. (2020). Hydroxychloroquine in patients with mainly mild to moderate coronavirus disease 2019: open label, randomised controlled trial. BMJ (Clinical research ed.), 369, m1849. https:// doi.org/10.1136/bmj.m1849

Tobaiqy, M., Qashqary, M., Al-Dahery, S., Mujallad, A., Hershan, A. A., Kamal, M. A., \& Helmi, N. (2020). Therapeutic management of patients with COVID-19: A systematic review. Infection Prevention in Practice, 2(3), 100061. https://doi.org/10.1016/j.infpip.2020.100061

Valle, J., Godby, T., Paul, D. P., 3rd, Smith, H., \& Coustasse, A. (2017). Use of Smartphones for Clinical and Medical Education. The health care manager, 36(3), 293-300. https://doi.org/10.1097/ HCM.0000000000000176

Volz, E., Hill, V., McCrone, J. T., Price, A., Jorgensen, D., O'Toole, Á., Southgate, J., Johnson, R., Jackson, B., Nascimento, F. F., Rey, S. M., Nicholls, S. M., Colquhoun, R. M., da Silva Filipe, A., Shepherd, J., Pascall, D. J., Shah, R., Jesudason, N., Li, K., Jarrett, R., ... Connor, T. R. (2021). Evaluating the Effects of SARS-
CoV-2 Spike Mutation D614G on Transmissibility and Pathogenicity. Cell, 184(1), 64-75.e11. https://doi. org/10.1016/j.cell.2020.11.020

Wang, B., \& Jiang, L. (2021). Principal Component Analysis Applications in COVID-19 Genome Sequence Studies. Cognitive computation, 1-12. Advance online publication. https://doi.org/10.1007/s12559-020-09790-w Wang, J., Tang, Y., Ma, Y., Zhou, Q., Li, W., Baskota, M., Yang, Y., Wang, X., Li, Q., Luo, X., Fukuoka, T., Ahn, H. S., Lee, M. S., Luo, Z., Liu, E., Chen, Y., \& COVID-19 Evidence and Recommendations Working Group (2020). Efficacy and safety of antibiotic agents in children with COVID-19: a rapid review. Annals of translational medicine, 8(10), 619. https://doi. org/10.21037/atm-20-3300

Watson, A. R., Wah, R., \& Thamman, R. (2020). The Value of Remote Monitoring for the COVID-19 Pandemic. Telemedicine journal and e-health : the official journal of the American Telemedicine Association, 26(9), 1110-1112. https://doi.org/10.1089/tmj.2020.0134

Weissman, D., Alameh, M. G., de Silva, T., Collini, P., Hornsby, H., Brown, R., LaBranche, C. C., Edwards, R. J., Sutherland, L., Santra, S., Mansouri, K., Gobeil, S., McDanal, C., Pardi, N., Hengartner, N., Lin, P., Tam, Y., Shaw, P. A., Lewis, M. G., Boesler, C., ... Montefiori, D. C. (2021). D614G Spike Mutation Increases SARS CoV-2 Susceptibility to Neutralization. Cell host \& microbe, 29(1), 23-31.e4. https://doi.org/10.1016/j.chom.2020.11.012

Wise J. (2021). Covid-19: The E484K mutation and the risks it poses. BMJ (Clinical research ed.), 372, n359. https://doi.org/10.1136/bmj.n359

Yang, Y., Zhou, Y., Liu, X., \& Tan, J. (2020). Health services provision of 48 public tertiary dental hospitals during the COVID-19 epidemic in China. Clinical oral investigations, 24(5), 1861-1864. https://doi. org/10.1007/s00784-020-03267-8

Yang, Z., Liu, J., Zhou, Y., Zhao, X., Zhao, Q., \& Liu, J. (2020). The effect of corticosteroid treatment on patients with coronavirus infection: a systematic review and meta-analysis. The Journal of infection, 81(1), e13-e20. https://doi.org/10.1016/j.jinf.2020.03.062

Yousefifard, M., Zali, A., Mohamed Ali, K., Madani Neishaboori, A., Zarghi, A., Hosseini, M., \& Safari, S. (2020). Antiviral therapy in management of COVID-19: a systematic review on current evidence. Archives of academic emergency medicine, 8(1), e45.

Zhou, X., Snoswell, C. L., Harding, L. E., Bambling, M., Edirippulige, S., Bai, X., \& Smith, A. C. (2020). The Role of Telehealth in Reducing the Mental Health Burden from COVID-19. Telemedicine journal and e-health : the official journal of the American Telemedicine Association, 26(4), 377-379. https://doi.org/10.1089/ tmj.2020.0068

Campbell, A. M. (2020). An increasing risk of family violence during the Covid-19 pandemic: Strengthening community collaborations to save lives. Forensic science international: reports, 2, 100089.

Nelson, A. (2020). COVID-19: Capitalist and postcapitalist perspectives. Human Geography, 13(3), 305-309. 


\section{ANNEXES}

Table 1. Details of the search strategies used in the current review

\begin{tabular}{|l|l|}
\hline Search Strategy Items & \\
\hline Used keywords & (SARS2, SARS-CoV-2, Wuhan Coronavirus, Novel Coronavirus, 2019-nCoV, coronavirus, COVID-19, and COVID-19) \\
\hline Searched databases & Science Direct, Web of Science, Embase, Scopus, and PubMed \\
\hline Time filter & December 2019-2021 \\
\hline Language filter & English only \\
\hline Document type filter & Peer-reviewed articles \\
\hline Inclusion criteria & $\begin{array}{l}\text { All studies reporting findings on the management and treatment of COVID-19, tools, and approaches used in this re- } \\
\text { gard, supervision of the training of healthcare workers during the pandemic, consultation services of the disease, triage } \\
\text { of patients, assessment of symptoms, diagnosis, and the provision of clinical services. }\end{array}$ \\
\hline Exclusion criteria & $\begin{array}{l}\text { All studies and articles, letters, opinion articles, review articles with irrelevant data, duplicate publications, and } \\
\text { articles with information that were inconsistent with the hypothesis were excluded. }\end{array}$ \\
\hline
\end{tabular}

Table 2. ROBIS risk assessment of bias in the systematic review summary

\begin{tabular}{|c|c|c|c|c|c|c|}
\hline \multicolumn{3}{|c|}{ Phase 1} & \multicolumn{4}{|c|}{ Phase 2} \\
\hline $\begin{array}{l}\text { Study } \\
\text { No/ } \\
\text { ID }\end{array}$ & $\begin{array}{l}\text { Author (s) } \\
\text { Year }\end{array}$ & $\begin{array}{c}\text { Eligibility } \\
\text { Criteria }\end{array}$ & $\begin{array}{c}\text { ID } \\
\text { Selection of } \\
\text { studies }\end{array}$ & $\begin{array}{c}\text { Data Collection } \\
\text { and Study } \\
\text { Appraisal }\end{array}$ & $\begin{array}{l}\text { Synthesis } \\
\text { and findings }\end{array}$ & $\begin{array}{l}\text { Risk of bias in } \\
\text { the review }\end{array}$ \\
\hline 1 & Adhikari et al. (2020) & $*$ & * & * & $*$ & \# \\
\hline 2 & Annis et al. (2020) & $*$ & \# & \# & \# & \# \\
\hline 3 & Antwi-Amoabeng et al. (2020) & \# & * & \# & \# & \# \\
\hline 4 & Binkin et al. (2020) & - & \# & * & \# & * \\
\hline 5 & Borges do Nascimento et al. (2020) & \# & \# & * & $*$ & \# \\
\hline 6 & Carinci (2020) & \# & \# & \# & \# & $*$ \\
\hline 7 & Chan et al. (2020) & $*$ & \# & \# & $*$ & \# \\
\hline 8 & Charles et al. (2020) & \# & $*$ & \# & \# & \# \\
\hline 9 & Davarpanah et al. (2020) & $*$ & $*$ & $*$ & $*$ & \# \\
\hline 10 & Dora et al. (2020) & \# & \# & \# & $*$ & \# \\
\hline 11 & Emanuel et al. (2020) & \# & $*$ & \# & \# & \# \\
\hline 12 & Fisher \& Heymann (2020) & $\#$ & \# & $\#$ & $\#$ & $*$ \\
\hline 13 & Fortney et al. (2007) & \# & \# & \# & \# & \# \\
\hline 14 & Fajgenbaum et al. (2020) & \# & $*$ & $*$ & \# & \# \\
\hline 15 & Fu et al. (2020) & \# & $*$ & \# & \# & $\#$ \\
\hline 16 & Gautret et al. (2020) & $*$ & $*$ & $*$ & \# & \# \\
\hline 17 & Gbinigie \& Frie (2020) & \# & \# & \# & \# & $*$ \\
\hline 18 & Goumenou et al. (2020) & \# & $\#$ & * & \# & $*$ \\
\hline 19 & Greenhalgh et al. (2020) & \# & \# & \# & $*$ & \# \\
\hline 20 & Grisolia et al. (2020) & $\#$ & $*$ & $\#$ & $\#$ & $\#$ \\
\hline 21 & Haines et al. (2020) & \# & $\#$ & * & $*$ & $\#$ \\
\hline
\end{tabular}




\begin{tabular}{|c|c|c|c|c|c|c|}
\hline \multicolumn{3}{|c|}{ Phase 1} & \multicolumn{4}{|c|}{ Phase 2} \\
\hline $\begin{array}{l}\text { Study } \\
\text { No/ } \\
\text { ID }\end{array}$ & $\begin{array}{l}\text { Author (s) } \\
\text { Year }\end{array}$ & $\begin{array}{c}\text { Eligibility } \\
\text { Criteria }\end{array}$ & $\begin{array}{c}\text { ID } \\
\text { Selection of } \\
\text { studies }\end{array}$ & $\begin{array}{c}\text { Data Collection } \\
\text { and Study } \\
\text { Appraisal }\end{array}$ & $\begin{array}{c}\text { Synthesis } \\
\text { and findings }\end{array}$ & $\begin{array}{c}\text { Risk of bias in } \\
\text { the review }\end{array}$ \\
\hline 22 & Howard et al. (2018) & \# & \# & \# & \# & \# \\
\hline 23 & Jewell et al. (2020) & $\#$ & $*$ & * & \# & \# \\
\hline 24 & Jia et al. (2017) & \# & \# & \# & \# & \# \\
\hline 25 & Jiang et al. (2020) & $*$ & $*$ & * & $*$ & \# \\
\hline 26 & Jnr (2020) & $*$ & $\#$ & \# & \# & $*$ \\
\hline 27 & Khalili et al. (2020) & $*$ & $*$ & * & \# & \# \\
\hline 28 & Krings et al. (2020) & \# & $*$ & \# & \# & \# \\
\hline 29 & Kucharski et al. (2020) & $\#$ & $\#$ & \# & \# & \# \\
\hline 30 & Leite et al. (2019) & \# & \# & \# & \# & \# \\
\hline 31 & Li et al. (2020) & $*$ & \# & \# & \# & \# \\
\hline 32 & Liu et al. (2020) & $\#$ & $\#$ & * & $*$ & $\#$ \\
\hline 33 & Lukas et al. (2020) & \# & \# & \# & \# & * \\
\hline 34 & Mainz et al. (2019) & \# & \# & * & \# & \# \\
\hline 35 & Marton \& Kanas (2016) & $*$ & \# & \# & \# & \# \\
\hline 36 & Mehrotra et al. (2016) & $*$ & \# & & \# & \# \\
\hline 37 & Mehra et al. (2020) & * & $*$ & \# & \# & \# \\
\hline 38 & Singh et al. (2020) & \# & \# & \# & \# & $*$ \\
\hline 40 & Monaghesh \& Hajizadeh (2020) & $*$ & \# & \# & \# & \# \\
\hline 41 & Ohannessian et al. (2020) & \# & \# & * & \# & \# \\
\hline 42 & Odone et al. (2020) & $*$ & \# & \# & \# & \# \\
\hline 43 & Pacheco \& Riera (2017) & $*$ & \# & * & \# & \# \\
\hline 44 & Rana \& Dulal (2020) & \# & \# & * & $*$ & \# \\
\hline 45 & Reeves et al. (2020) & $*$ & $*$ & \# & \# & \# \\
\hline 46 & Sanyaolu et al. (2020) & * & \# & \# & \# & \# \\
\hline 47 & Sauers-Ford et al. (2020) & $*$ & $*$ & \# & \# & \# \\
\hline 48 & Shaker et al. (2020) & \# & $*$ & \# & \# & \# \\
\hline 49 & Smith et al. (2020) & \# & \# & \# & \# & $*$ \\
\hline 50 & Tang et al (2020) & $*$ & \# & \# & \# & \# \\
\hline 51 & Tang et al. (2020) & \# & \# & \# & \# & \# \\
\hline 52 & Tobaiqy et al. (2020) & $*$ & $*$ & \# & \# & \# \\
\hline 53 & Wang et al. (2020) & \# & $*$ & \# & \# & \# \\
\hline 54 & Watson et al. (2020) & \# & \# & \# & \# & \# \\
\hline 55 & Yang et al. (2020) & $*$ & \# & \# & $\#$ & \# \\
\hline 56 & Yang et al. (2020) & \# & \# & * & \# & \# \\
\hline 57 & Yousefifard et al. (2020) & $*$ & $*$ & \# & \# & \# \\
\hline 58 & Zhou et al. (2020) & $*$ & \# & \# & \# & \\
\hline
\end{tabular}

Note. '*' = high risk;' \# '= low risk; ID = identification; In the ROBIS system each domain is guided by few signaling questions. 
Chijioke Gospel Tonycheta

SYSTEMATIC REVIEW OF COVID-19 TREATMENT AND MANAGEMENT

Table 3. Summary of studies included in the current systematic literature review

\begin{tabular}{|c|c|c|c|c|c|c|c|c|c|}
\hline$\frac{0}{2}$ & Authors & Country & Duration & $\mathbf{N}$ & $\begin{array}{l}\text { Research } \\
\text { Design }\end{array}$ & Barriers & Facilitators & Result & Conclusion \\
\hline 1 & $\begin{array}{l}\text { Antwi- } \\
\text { Amoabeng et } \\
\text { al. }(2020)\end{array}$ & US & 5 months & 352 & $\begin{array}{l}\text { Systematic } \\
\text { review }\end{array}$ & \# & \# & Sig. & $\begin{array}{l}\text { anti-IL6 results in the } \\
\text { improvement of this hyper- } \\
\text { inflammatory state }\end{array}$ \\
\hline 2 & $\begin{array}{l}\text { Davarpanah et } \\
\text { al. }(2020)\end{array}$ & Iran & 6 days & 1138 & RCT & $\begin{array}{l}\text { using a broader defini- } \\
\text { tion of infection to in- } \\
\text { clude all positive cases } \\
\text { on chest CT resulted } \\
\text { in a higher number of } \\
\text { false/positive cases }\end{array}$ & $\begin{array}{l}\text { the Iranian } \\
\text { Society of } \\
\text { Radiology } \\
\text { COVID-19 } \\
\text { Consultants } \\
\text { (ISRCC) }\end{array}$ & Sig. & $\begin{array}{l}\text { Novel screening and triage } \\
\text { strategy }\end{array}$ \\
\hline 3 & $\begin{array}{l}\text { Gautret et al. } \\
(2020)\end{array}$ & France & 3 weeks & 36 & CT. & A small sample size & \# & Sig. & $\begin{array}{l}\text { hydroxychloroquine } \\
\text { treatment is significantly } \\
\text { associated with viral load } \\
\text { reduction/disappearance in } \\
\text { COVID-19 patient }\end{array}$ \\
\hline 4 & $\begin{array}{l}\text { Khalili et al. } \\
(2020)\end{array}$ & Iran & 7 months & 846 & $\begin{array}{l}\text { Systematic } \\
\text { review }\end{array}$ & methodological flaws & \# & Sig. & $\begin{array}{l}\text { significant methodological } \\
\text { flaws limiting definite } \\
\text { conclusions about the } \\
\text { efficacy and safety of } \\
\text { therapeutic interventions }\end{array}$ \\
\hline 5 & $\begin{array}{l}\text { Krings et al. } \\
(2020)\end{array}$ & US & \# & 68 & \# & \# & $\begin{array}{l}\text { the Europe- } \\
\text { an Union's } \\
\text { Horizon }\end{array}$ & Sig. & $\begin{array}{l}\text { Performance intelligence } \\
\text { guides the decisions of } \\
\text { health system actors }\end{array}$ \\
\hline 6 & $\begin{array}{l}\text { Mehra et al. } \\
(2020)\end{array}$ & US & \# & 78 & $\begin{array}{l}\text { Systematic } \\
\text { Review }\end{array}$ & $\begin{array}{l}\text { Surgisphere would } \\
\text { not transfer the full } \\
\text { dataset, client con- } \\
\text { tracts, and the full } \\
\text { ISO audit report to } \\
\text { servers for analysis }\end{array}$ & \# & Sig. & Sig. \\
\hline 7 & $\begin{array}{l}\text { Monaghesh } \\
\& \text { Hajizadeh } \\
(2020)\end{array}$ & US & $\#$ & 8 & $\begin{array}{l}\text { systematic } \\
\text { review }\end{array}$ & $\begin{array}{l}\text { All current evidence } \\
\text { cannot be general- } \\
\text { ized }\end{array}$ & \# & Sig. & $\begin{array}{l}\text { Telehealth improves the } \\
\text { provision of health services }\end{array}$ \\
\hline 8 & $\begin{array}{l}\text { Pacheco \& } \\
\text { Riera (2020) }\end{array}$ & Brazil & \# & 58 & $\begin{array}{l}\text { Rapid } \\
\text { systematic } \\
\text { review }\end{array}$ & $\begin{array}{l}\text { Studies used differ- } \\
\text { ent evaluation tools }\end{array}$ & \# & \# & $\begin{array}{l}\text { The efficacy and safety of } \\
\text { hydroxychloroquine and } \\
\text { chloroquine in patients with } \\
\text { COVID-19 is still uncertain }\end{array}$ \\
\hline 9 & $\begin{array}{l}\text { Reeves et al. } \\
(2020)\end{array}$ & US & \# & \# & $\#$ & \# & \# & Sig. & $\begin{array}{l}\text { An electronic health } \\
\text { record is an essential tool } \\
\text { in supporting the clinical } \\
\text { needs }\end{array}$ \\
\hline 10 & $\begin{array}{l}\text { Tobaiqy et al. } \\
(2020)\end{array}$ & US & 4 months & 41 & $\begin{array}{l}\text { systematic } \\
\text { review }\end{array}$ & \# & \# & Sig. & Effective \\
\hline 11 & $\begin{array}{l}\text { Wang et al. } \\
(2020)\end{array}$ & China & \# & 6 & $\begin{array}{l}\text { Rapid } \\
\text { systematic } \\
\text { review }\end{array}$ & $\begin{array}{l}\text { Small sample for } \\
\text { generalization }\end{array}$ & \# & NS & $\begin{array}{l}\text { The benefits of antibiotic } \\
\text { agents for adults with } \\
\text { SARS or MERS were } \\
\text { questionable in the absence } \\
\text { of bacterial coinfections }\end{array}$ \\
\hline 12 & $\begin{array}{l}\text { Yang et al. } \\
(2020)\end{array}$ & China & \# & 48 & $\begin{array}{l}\text { Clinical oral } \\
\text { investigations }\end{array}$ & \# & \# & Sig. & $\begin{array}{l}\text { There was a significant } \\
\text { change in the health } \\
\text { service provision }\end{array}$ \\
\hline 13 & $\begin{array}{l}\text { Yousefifard et } \\
\text { al. (2020) }\end{array}$ & US & \# & 21 & $\begin{array}{l}\text { systematic } \\
\text { review }\end{array}$ & $\begin{array}{l}\text { Inconsistent infor- } \\
\text { mation }\end{array}$ & \# & NS & $\begin{array}{l}\text { The current evidence } \\
\text { impedes researchers from } \\
\text { proposing an appropriate } \\
\text { antiviral therapy against } \\
\text { COVID-19 }\end{array}$ \\
\hline
\end{tabular}

